\title{
Improvement of Life Skills through Handwashing Habit (Action Research on Children of Group A in Kindergarten Al- Fidaa Bekasi, Indonesia)
}

\author{
Edy Mustofa ${ }^{1}$, Khausar $^{2}$ \\ ${ }^{1}$ Lecturer in STIT Al-Marhalah Al-Ulya, Bekasi, Indonesia \\ ${ }^{2}$ Lecturer in STKIP Bina Bangsa Meulaboh, Indonesia \\ edymustofaa24@yahoo.co.id
}

\begin{abstract}
Life Skills is an ability possessed by someone to behave positively, self-regulate, and socially skilled. Handwashing habit is an activity carried out in an action or behavior that trains children to have proper handwashing skills. This study aims to determine the improvement of life skills through the habit of washing hands. This type of research is action research. The subjects in this study were the children of Group A Al-Fidaa Kindergarten (TK), Tambun Selatan District, Bekasi Regency, Indonesia, totaling 10 children. This study consisted of 2 cycles, each cycle carried out as many as 8 meetings. The results showed that through the habit of washing hands can improve children's life skills. The results of the study of children's life skills in pre-cycle that is equal to $40 \%$ and increased in the first cycle to $65 \%$ then increased to $89 \%$ in the second cycle with a very well developed category.
\end{abstract}

Keywords: Life skills; handwashing habit; action research.

\section{Introduction}

Early childhood is an individual figure as a sociocultural being who is undergoing a process of development that is fundamental to the next life and has a number of certain characteristics. Early childhood is an organism which is an intact physical and spiritual unity with all its biological and psychological structures and devices so that it becomes a unique figure. Early childhood experiences a fundamental development process in the sense that development experiences at an early age can have a lasting and lasting effect so that they underlie the process of subsequent child development. Every child has a number of potentials, physical-biological potential, cognition, and socio-emotion. Children who are experiencing a very rapid development process that requires active and energetic learning.

In addition, the kindergarten development program (TK) must be able to instill and foster behavioral and behavioral guidance carried out through special skills education that provides basic provisions and exercises properly carried out to students about the values of daily life so the relevant is able, able, and skilled to carry out his life that is able to maintain its survival and development, which is often referred to as life skills.

This was confirmed by Rakesh Sandhu (2014; 389) said:

"Life skills assist the students to face the challenges of everyday life. Life skill enhances the capabilities of the students so as to become healthy, responsible and productive citizens. Young people are considered the major agents in their own development, which means that they have the ability to create the supportive relationships and communities they need to grow and thrive".

Education is an obligation for every community both young and old. Khausar (2018: 42). In general, life skills oriented education (Life Skill) for students is as a provision in dealing with and solving life and life problems, both as independent individuals, community members, and as citizens.

From a number of opinions above life skills should be started at an early age. Because early childhood education is the basis for developing the potential that exists in children in the 
form of skills including handwashing skills. This is very important to enter the next level of basic education, and can develop various skills needed in later life.

Based on the results of preliminary observations at Al-Fidaa Kindegarden, researchers found activities at the kindergarten had not yet developed life skills education. This can be seen from a series of activities that do not reflect skills or habituation such as handwashing skills which should use soap and running water, but the phenomenon found in the field of children washing their hands not with soap and running water, but children only washing their hands while want to eat with water in a bucket.

Reality in the field in Group A Al-Fidaa kindergarten with 10 children. Of the 10 children, there are 9 children $(71 \%)$ who have not been able to improve life skills through the habit of washing their hands. So in writing this study the authors want to improve life skills (life skills) through habituation of washing.

Therefore, to solve the above problems, researchers try to find a way out with efforts to improve learning through classroom action research, so as to create an interesting learning atmosphere and can motivate children to follow it with good and proper handwashing habits.

\section{Theory of Literature}

According to the definition of the World Health Organization (WHO, 2010), life skills $\mathrm{p}$ are the ability to behave in an adaptive and positive manner that enables a person to effectively solve everyday needs and challenges.

Then According to Anwar (2006; 20) Life Skills include a minimum of five parts; 1.Selfawareness skills, which are also often referred to as personal skills, 2 Rational thinking skills, 3.Social skills, 4.Academic skills, 5.Vocational skills. The five fields should be given simultaneously to students, even as long as they are still in preschool education where their conditions are still a period of character formation which will color the future.

Besides life skills according to Brolin in Anwar (2006: 20) explained that Life Skills constitute a continuum of knowledge and attitude that are necessary for a person to function effectively and to cause interruptions of employment experience.

Besides life skills according to Brolin in Anwar (2006: 20) explained that Life Skills (life skills) constitute a continuum of knowledge and attitude that are necessary for people to function effectively and to cause interruptions of employment experience.

According to Anwar Arsyad (2007: 55) Life Skills are skills possessed by someone to want and dare to face life's problems and life naturally without feeling depressed, then proactively and creatively seek and find solutions so that they are finally able to overcome them. Another understanding says that life skills are skills that enable a person to cope with the stresses and challenges of life. Satori in Anwar (2006: 20) said the development of life skills originated from (1) the world of work, (2) practical living skills, (3) personnel growth and management, and (4) social skills.

Thus life skills is an ability possessed by someone to behave positively, self-regulate, and socially skilled. Handwashing habit is an activity carried out in thinking, behaving and acting in accordance with the desired goals, namely actions or behaviors to train children to have proper handwashing skills. This is confirmed by Behaviorist Theories of Thorndike (1940) suggesting that learning in animals and humans basically takes place according to the same principles. Learning can occur if there is a stimulus and response (S-R). 


\section{Research Method}

This type of research uses the action research method (action research) to get accurate results, this action research flow refers to the action research model proposed by Kurt Lewin in Jean Mc Niff $(2013 ; 60)$ describing action research as a spiral of steps, which each step has 3 stages, namely: (1) planning, (2) Acting and Observing, (3) Reflecting as Cycle I. The next step is Cycle II, which is carried out by making changes to certain parts based on the reflection of cycle $\mathrm{I}$, in accordance with the learning plan that has been prepared. The aim of the activity is to improve aspects that were considered unsuccessful in cycle I. The results obtained in cycle II were analyzed and compared with cycle I and then used to measure the success of cycle II. The steps used are the same as those done in the cycle.

The subjects in this study were the children of group A Kindergarten Al-Fidaa Tambun Selatan District, odd semester of the 2014/2015 Academic Year, amounting to 10 children. This research was conducted at TK Al-Fidaa Sub district, South Tambun, Bekasi. Research Time The research was carried out, starting in February until April 2015. Data collected in this study are: (1) Field notes; (2) The documentation of the data source is a child of Group A TK Al-Fidaa; (3) Students taken as research subjects are children of group A TK Al-Fidaa.

The technique of data analysis used in this study is through two ways, namely qualitative data analysis and quantitative data analysis. Qualitative data analysis, namely analyzing data that occurs in the learning process through the habit of washing hands, from the initial observation to the implementation of the cycle with the implementation procedures include planning, implementation, observation and reflection. Data that arises from qualitative data is in the form of words rather than a series of numbers. Qualitative data analysis using techniques according to Miles and Huberman (1984) consisting of: data reduction, data display, and conclusion drawing / verification.

While quantitative data, namely the test scores obtained by children in activities using the habit of washing hands, were assessed by the observer through an instrument in the form of an observation sheet. The intended test score is the score obtained at the time of the initial assessment and the test taken at the end of the cycle. Quantitative data were analyzed using descriptive statistics presented in tabular / graphical form. To see the results of the action used a study of the proportion of the average value before and after getting action.

To see an increase in the average achievement of children's life skills through the habit of washing hands compared to the target score, a study of the proportion of average scores of children before treatment and after treatment was used. In addition to making it easier to interpret the results, the number of results with the following formula:

$$
\mathrm{P}=\frac{\sum X}{N}
$$

\section{Percentage of increase $=$ Percentage of cycle $I$ - Percentage of pre-study}

The success of the action was concluded using analysis, which was declared successful if the average percentage of children's life skills assessment was above $71 \%$ or as many as 7 children out of 10 children increased after being given an action through habitual hand 
washing. To prove the percentage increase in research success by referring to the description of the results of the study showed $71 \%$.

\section{Discussion}

This action research was carried out in Group A Al-Fidaa Kindergarten as many as 2 cycles. Broadly speaking the results of research data are children's life skills in pre-cycle that is equal to $40 \%$ and increased in the first cycle to $65 \%$ then increased to $89 \%$ in the second cycle with a very well developed category. Data on life skills improvement for children of Group A TK Al-Fidaa can be presented as follows:

Table 1. Life skills of Group A kindergarten children Al-Fidaa

\begin{tabular}{cccc}
\hline Stages & Pre Cycle & Cycle I & Cycle I \\
\hline Score & & & 89 \\
Average & 40 & 65 & 89 \\
\hline
\end{tabular}

From the table above, it can be seen how the life skills of Group A kindergarten children Al-Fidaa are improved. In cycle II the average TCP child has reached the success criteria determined by researchers and collaborators so that this action research is said to have succeeded.

From the findings of research on increasing children's life skills through handwashing activities can be revealed below:

a. Child Action Process. Findings in the child's action process when participating in handwashing activities that can improve children's life skills through two processes namely a) curiosity and b) children's participation in learning activities. The findings in the learning process in the form of children's curiosity that arises when the teacher conveys information about learning material, makes learning activities more interactive. The questions that children give to teachers can enrich children's knowledge about learning and improve children's skills. From this activity the increase in children's life skills is increasingly increasing. Findings in the process of children's participation in learning activities, namely: a) Attention, when the teacher explains and gives guidelines for activities, the child is enthusiastic in listening and seeing what the teacher says and does. b) Active participation of children in working on learning activities or practices is very helpful in achieving the objectives of the child's handwashing activities increasingly encouraged by the involvement of children directly. c) Positive responses, in the form of the joy felt by children in learning activities are seen when learning is done, especially when children are given the freedom to do what is on their minds. Children don't look bored. This feeling of pleasure is very helpful for the smooth learning activities carried out and also the child receives the material more quickly and remembers it.

b. Process of Teacher's Action. Findings in the teacher's action process when doing handwashing activities. (a) Every teacher meeting always prepares the room before 
carrying out learning with the aim of the child feeling comfortable when doing the play process.

(b) Every meeting the teacher always prepares media material used in the learning process, while the tools related to handwashing activities that must be prepared are running water, gallons, liquid soap and disposable cloths. c) At each meeting, the teacher looks at the readiness of the child before carrying out the learning activities. The teacher tries to provide motivation and pareses every time a play activity is carried out, so that the children are eager to participate in the learning. (d) Adjust the sitting position of the child before engaging in learning activities, this is done by the teacher in the context of good classroom management, various sitting formations are arranged in such a way condition of the child. (e) The teacher accompanies the initial activities, greetings, greetings and pray. This activity is carried out at circle time so that it becomes a good habit for children. (f) The teacher presents material related to the aspect to be observed. (g) In washing hands, children are given assistance in each activity. This activity aims to develop children's creativity in expression.

c. Children's Life Skills Findings. Findings in the process of child action through handwashing activities. (a) In the aspect of personal skills of all children in carrying out skills related to personal skills included in the category of skilled, activities related to these skills such as activities of children to distinguish clean and dirty water and running water, able to carry out creative play activities, children understand the benefits washing hands, able to eat alone. At this stage the child is perfectly capable, because the child has begun to focus on doing activities. The child's eye hand coordination is perfectly perfect. So the teacher does not have to guide the child in carrying out activities. (b) In self-regulation skills such as activities observed through the habit of children washing their hands before and after activities, the child is accustomed to listening to what is instructed by the teacher, the child is able to obey applicable regulations, and is accustomed to cleaning hands with soap. This skill also makes children able to mimic shapes well. (c) In social skills there is an increase in children at a skilled level in this aspect, the indicator is shown in the child's ability in the child's ability to share experiences with friends, set true examples to friends, tell rare steps to wash hands properly, invite friends to do washing hands, children are able to work with friends and like to help friends in activities.

Based on the results of quantitative data analysis, the percentage obtained from an increase in children's life skills in the second cycle of $89 \%$ results can indicate conformity with the action hypothesis, namely a percentage increase of at least $71 \%$, then the hypothesis is accepted. Based on this, through handwashing activities can increase the life skills of children aged 4-5 years at the Al-Fidaa Bekasi Kindergarten received.

The results of qualitative data analysis prove that through handwashing activities can improve children's life skills, one of them looks children are skilled in using balanced rightleft hands, children are skilled in stationery. Children are very enthusiastic to actively participate in learning activities. Children's courage in asking or answering questions is increasing, as according to opinions (2007: 55) regarding indicators of Life Skills. Likewise with the child's confidence to tell the thrill of his experience after doing handwashing activities in front of his friends. 
In learning activities, researchers provide action at each meeting through handwashing activities. The researcher discusses the theme and continues with introducing the children to the objects that are explained based on the theme, the benefits of the use of objects / tools / plants / animals in accordance with the sub-theme activities. So as to stimulate life skills can be increased.

In each handwashing activity, it is intended that every aspect of a child's life skills be optimally improved. Materials for play are provided directly by researchers. The increase occurred during 11 meetings in 2 cycles. By using indicators that are used as a reference to get data. Based on the description above, it can be stated that through washing hands, in addition to improving children's life skills, children also get new experiences from various things, so that in line with the explanation of Brolin in Anwar (2006: 20) and Albert Bandura (1997: 5) that children learn from the experiences of the surroundings.

Researchers found strengths and weaknesses in handwashing activities in learning. The advantage gained is that researchers can make their own materials used by children in play activities, the costs used are relatively more efficient, in the use of play materials are also more effective and not difficult for children to use them in play activities. The weakness of the activity of washing hands is its individual nature, cannot be done together. And, it can only be done at certain times.

In every meeting of children's life skills slowly beginning to be seen the habit of washing hands can help provide motivation in improving life skills. One of them is the provision of media as a facility for children to hone their life skills. Selling is the activity of washing hands, able to make children who are difficult to discipline, children who normally do not want to learn, children who are lazy to eat can do this.

Furthermore, handwashing activities, in addition to improving children's life skills, are able to improve children's social skills with their peers, from this activity they collaborate and have active communication with friends and teachers, this is in line with what Hurlock (1978) stated in Winda et.al. (2008: 32) that good mastery of life skills can help children in social adjustment with their friends, making children more confident.

Through life skills children can entertain themselves and get a feeling of pleasure, can support the development of self-confidence. Through life skills children can adjust themselves to the school environment (school adjustment), at pre-school age (kindergarten) or elementary school age early elementary school. If seen from the meetings that have been held, washing hands in every learning activity can make children motivated. This is seen in children who are happy with learning that is direct practice. Because children learn from something concrete, this is in line with the opinion of Piaget (1929) in Winda Gunarti et.al. (2008: 1.4) that children will easily learn from concrete objects. Although at first it was unusual to wash hands before and after long activities, the habit grew into pleasant feelings.

\section{Conclusion}

Based on the findings and discussion, this study concludes that the process of increasing life skills through the habit of washing hands can improve three aspects of personal skills, selfregulation and social skills. Personal improvement where children are accustomed to washing hands with liquid soap according to good standards (WHO and RI Health Ministry Rules) before, during and after activities. Children are also able to distinguish between clean 
and dirty water and running water and stagnant water, so that children can get used to washing their hands properly. Increased social skills, including children can give examples of how to wash hands with their peers, build togetherness for healthy living behaviors or maintain personal hygiene. Besides that, regarding the regularity of one, they tend to develop disciplinary behavior, realizing the need to wash their hands and control themselves in their activities. Thus, through the habit of daily hand washing, students have the inner qualities and outward actions that are ready to face a healthy future life so that the person is capable and able to maintain their survival and development.

\section{Suggestion}

Based on the conclusions and implications, the following suggestions for improving life skills through handwashing habit include the following: (1) Habitual habits of life (life skills) of children have not been well paid attention to, this can be seen from children children who have not behaved positively in learning activities such as the lack of knowledge in terms of good and proper hand washing. The habit of washing hands is very well applied in schools to equip children in life skills and is sensitive to personal and environmental hygiene. (2) Specifically for education providers to develop life skills learning programs (life skills) can be incorporated into learning activities into themes and sub-themes. Through the habit of washing hands, children learn new ways to improve their life skills. The teacher's role is very important to remind and motivate the habit of washing hands before and after learning activities. So children can practice in everyday life. (2) To parents that habituation of life skills is very important for children; parents should be able to set an example of positive role models at home, especially in the case of washing hands.

\section{References}

AF Widmer, 2000. Replace Handwashing with Use of a Waterless Alcohol Hand Rub?, Clinical Infectious Disease

Anwar. 2006. Pendidikan Kecakapan Hidup: Konsep dan Aplikasi. Alfabeta : Bandung.

Arsyad, Anwar. 2007. Media Pembelajaran. Jakarta: Raja Grafindo Persada Piran \& Sasonohardjo, 2002. Media Pembelajaran. Jakarta: Lembaga Administrasi Negara

Asra, et.al. 2007. Komputer Dan Media Pembelajaran Di SD. Jakarta: Direktorat Jenderal Pendidikan Tinggi. Departemen Pendidikan Tinggi.

David Hopkins. 1993. A Teacher Guide to Classroom Research. Third Edition. philadelpia: open University Press.

Depkes RI. 2008. Panduan Manajemen PHBS Menuju Kabupaten/Kota Sehat. Jakarta: Depkes RI.

Diadopsi dari WHO. 2009. guidelines on hand hygene in health care : First Global Patient Safety Challenge, World Health Organization.

Firman Eko, et.al. 2014. Hubungan Peran Orang Tua Dalam Promosi Kesehatan Dengan Pelaksanaan Cuci Tangan Pada Anak Usia Pra sekolah. http://www.qjournal.co.id/paper-285-hubungan-peran-orang-tua-dalampromosikesehatan-dengan-pelaksanaan-cuci-tangan-pada-anak-usiaprasekolah.html.pukul 20:34. 31/05/. 
Jean Mc. Niff, 2013. Action Research, Principle and Practice, (USA: Rautledge,).

Khausar, K. 2018. Upaya dan peran institusi lokal (balee inong) dalam menanamkan nilainilai pendidikan islam bagi ibu-ibu dan remaja Kota Banda Aceh. genta mulia: jurnal ilmiah pendidikan.

Linda, et al, 2010. Panduan Pencegah Infeksi Untuk Fasilitas Pelayanan Kesehatan Dengan Sumber Daya Terbatas, (Yayasan Bina Pustaka Sarwono Prawirohardjo bekerja sama dengan JNPKKR/POGI dan JHPIEGO (Program Mnh \& Starh). Jakarta.

Milles, M.B. and Huberman, M.A. 1984. Qualitative Data Analysis. London: Sage Publication

Nur Aisah, 2014. Meningkatkan Kemampuan Mencuci Tangan Melalui Metode Demonstrasi. Kelompok B Di Tk Unggulan Terpadu Al Kautsar Mojokerto, Jurnal Ilmiah, Universitas Negeri Surabaya, Surabaya). http://jurnal.untan.ac.id/index.php/jpdpb/article/viewFile/4203/4220 diakses pada 19:57 $31 / 05 /$.

Sandhu Rekash, 2014. A. Study of Skills of Pupil Teacher. Indian Journal of Fundamental and aplplied life science. p.389.

Udin S. Winataputra, et al. 2007Teori Belajar dan pembelajaran. Jakarta: Universitas Terbuka

Winda Gunarti, et al. 2008. Metode Pengembangan Perilaku dan Kemampuan Dasar Anak Usia Dini. Jakarta. 